\title{
ANALISIS PENGARUH BUDAYA ORGANISASIONAL DAN KEPUASAN KERJA TERHADAP KOMITMEN ORGANISASIONAL DAN KINERJA BIDAN PADA RSUD KOTA MATARAM
}

\author{
Baiq Sukmawati ${ }^{1}$, Lalu Suparman ${ }^{2}$, Surati ${ }^{3}$ \\ 1Program Studi Magister Manajemen Fakultas Ekonomi dan Bisnis Unram, \\ baiqsukmawati.mm@gmail.com \\ 2,3Fakultas Ekonomi dan Bisnis, Universitas Mataram
}

\begin{abstract}
ARTICLE INFO
Keywords :

Organizational Culture, Job Satisfaction, Organizational Commitment, Midwife Performance.

How to cite :

Sukmawati,Baiq., Suparman, Lalu., Surati., (2019). Analisis Pengaruh Budaya Organisasional Dan Kepuasan Kerja Terhadap Komitmen Organisasional Dan Kinerja Bidan Pada RSUD Kota Mataram, 8(3), 244-257
\end{abstract}

DOI :

http://dx.doi.org/10.29303/jmm.v8i3.449

$\begin{array}{ll}\text { Dikumpulkan } & \text { : 13 Juli } 2019 \\ \text { Direvisi } & \text { :16 Juli } 2019 \\ \text { Dipublikasi } & \text { : 17 Juli } 2019\end{array}$

\section{ABSTRACT}

This study examined the influence of organizational culture and job satisfaction on organizational commitment and performance of midwives in the Mataram City Public Hospital. Specifically the purpose of this study was to determine the significance of the influence of organizational culture, job satisfaction and organizational commitment on the performance of midwives, to know the significance of organizational culture and job satisfaction on organizational commitment, and to know the mediating role of variable organizational commitment in midwives in Mataram City Hospital. The study population was 72 midwives in charge of the RSUD Kota Mataram. This study uses structural equation model analysis (SEM analysis) with smartPLS applications. The results showed that organizational culture and organizational commitment had a significant positive effect on the performance of midwives, while job satisfaction did not significantly affect performance. Organizational culture and job satisfaction have a significant positive effect on organizational commitment. For the influence of mediation on organizational commitment, there is a full mediating role in the influence of job satisfaction on midwife performance, while the influence of organizational culture on the performance of midwives is found to have a partial mediation effect.

Penelitian ini menguji pengaruh antara budaya organisasional dan kepuasan kerja terhadap komitmen organisasional dan kinerja bidan di RSUD Kota Mataram. Secara spesifik tujuan dari penelitian ini adalah untuk mengetahui signifikansi pengaruh budaya organisasional, kepuasan kerja dan komitmen organisasional terhadap kinerja bidan, mengetahui signifikansi pengaruh budaya organisasional dan kepuasan kerja terhadap komitmen organisasional, serta mengetahui peran mediasi dari 


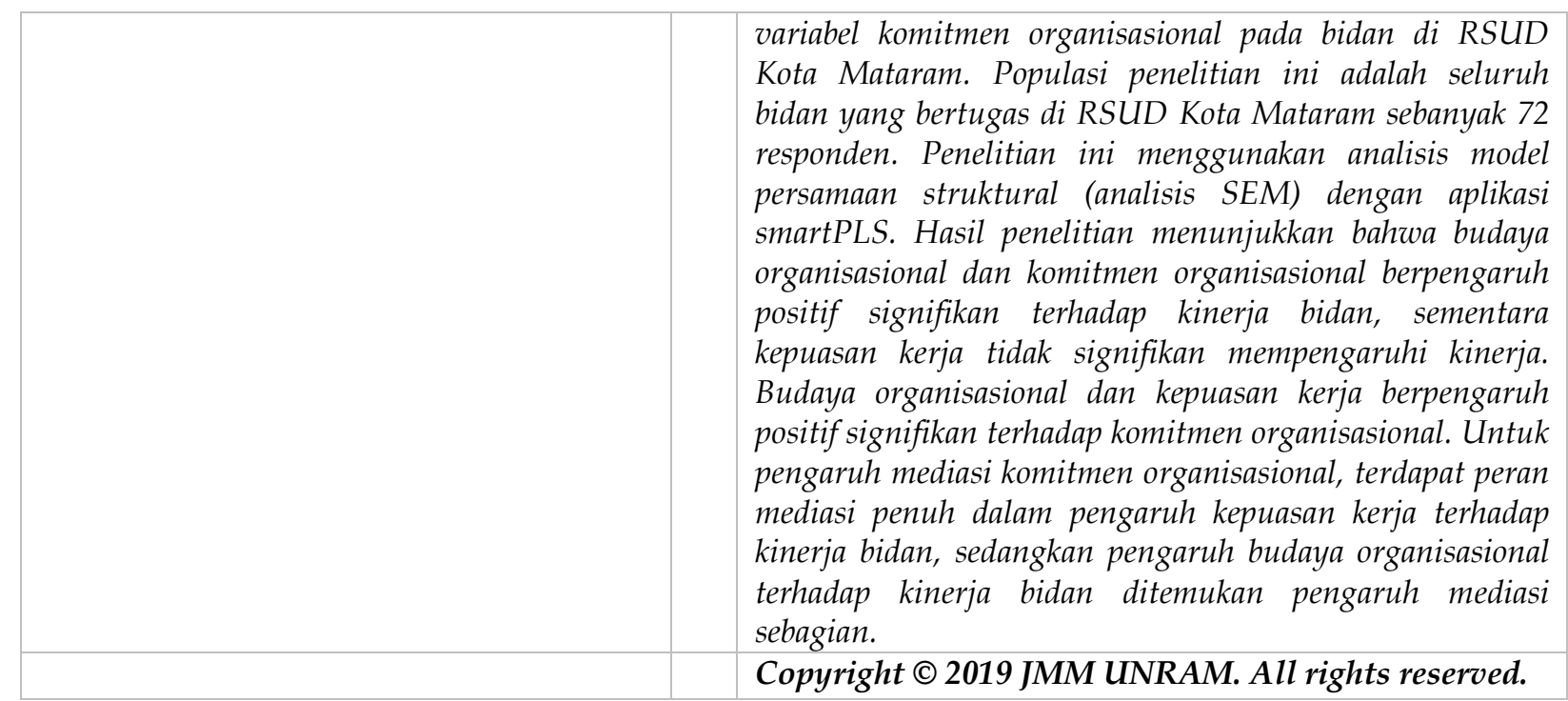

\section{PENDAHULUAN}

Rumah Sakit Umum Daerah (RSUD) Kota Mataram merupakan salahsatu institusi yang menawarkan jasakesehatan. Rumah sakit tentunyajuga memiliki tujuan-tujuan daripendiri rumah sakit bersangkutanyaitu misi dalam pelayanan sosialdan bisnis. Misi pelayanan sosialtentunya memberikan pelayananmedis, sedangkan bisnis rumah sakit adalahpencapaian keuntungan dalam bataskewajaran sehingga dapatmempertahankan kelangsunganhidup rumah sakit dan juga dalamrangka ekspansi kegiatan rumahsakit.Seiring dengan tuntutan peningkatan kualitas layanan kesehatan yang prima, maka RSUD Kota Mataram telah melengkapi peralatan kesehatannya menggunakan teknologi terkini seperti yang terdapat pada rumah sakit modern. Selain itu, faktor SDM juga menjadi fokus RSUD Kota Mataram.

Berdasarkan pada data penelitian pendahulaun diketahui bahwa kinerja RSUD Kota Mataram masih belum optimal. Capaian kinerja yang diharapkan juga masih belum terpenuhi. Mengingat tanggung jawab yang dibebankan kepada RSUD Kota Mataram, serta guna mewujudkan tercapainya kontrak kinerja yang telah disepakati perlu dilakukan analisis dan evaluasi. Hal ini bertujuan untuk melihat sejauh mana upaya dan hasil pencapaian pelaksanaan program kesehatan yang telah dilakukan selama beberapa tahun terakhir dibandingkan dengan kebijakan, sasaran dan program/kegiatan yang telah dilaksanakan. Belum optimalnya kinerja karyawan di lingkungan RSUD Kota Mataram menurut pengamatan penulis terdapat pada masih rendahnya kualitas kinerja karyawan, terutama bidan.

Lemahnya kinerja bidan akan berdampak pada buruknya kualitas kerjanya yang ditunjukkan antara lain: tingginya angka kemangkiran (absensi) bidan, sering terlambatnya bidan masuk kantor atau pulang lebih cepat dari jam yang telah ditentukan, menurunnya semangat dan gairah kerja, sering terjadinya konflik antar bidan, tidak terlaksananya supervisi, kurangnya kinerja bidan yang menganut budaya-buadaya organisasi yang diterapkan, serta pasien tidak diberikan pelayanan yang bagus baik dari biologis, psikologis, sosiologis dan spiritual. Dampak dari kinerja yang rendah akan menurunkan komitmen bidan dalam memberikan asuhan kebidanan. Tingkat profesionalisme bidan dalam melakukan tindakan asuhan kebidanan dipengaruhi oleh kuatnya budaya 
organisasional rumah sakit. Sehingga karyawan dapat menumbuhkan komitmen organisasional, mengerti tujuan organisasi serta mengerti perilaku mana yang dipandang baik dan tidak baik. Akan tetapi tidak semua rumah sakit memiliki budaya yang kuat dan kekuatan budaya di suatu rumah sakit bisa berbeda-beda.

Berdasarkan kajian visi dan misi RSUD Kota Mataram dan hasil penilaian budaya organisasional rumah sakit, bahwa bidan yang sudah mampu menerapkan budaya yang telah diterapkan rumah sakit sebanyak 20 persen. Budaya organisasional dengan jargon SMILE (Senyum, Mutu Inovatif, Lengkap, Efisien) pada RSUD Kota Mataram hanya mampu dilaksanakan dengan baik oleh bidan yang berstatus PNS. Dapat diasumsikan bahwa budaya organisasional belum melekat cukup erat pada bidan dengan status pegawai kontrak. Sehingga dari sisi praktik profesional masih perlu ditingkatkan khususnya dalam pelaksanaan standar asuhan dan standar operasional prosedur. Jadi berdasarkan fenomena tersebut dapat dinyatakan bahwa budaya yang diterapkan di rumah sakit belum sepenuhnya dapat mencerminkan keprofesionalan seorang bidan.

Beberapa keadaan yang terjadi pada bidan dengan status tenaga kontrak diantaranya adalah kurangnya kesadaran bidan dalam meningkatkan integritas dan profesionalisme pribadi melalui peningkatan dan kemampuan yang sesuai dengan teknologi dan kondisi aktual. Tidak adanya sanksi yang jelas dan tegas jika bidan bekerja tidak tepat dan tidak cepat. Kedisiplinan dan keteraturan kerja bidan masih rendah, terbukti masih banyak bidan terlalu sibuk dengan urusan pribadi diluar pekerjaanya. Peraturan disiplin kerja dan keteraturan kerja sudah dituangkan dalam prosedur-prosedur kerja yang lengkap namun belum dilaksanakan dengan baik, masih formalitas, dan jauh dari aktualisasi dalam bentuk perbuatan nyata. Dedikasi dan loyalitas bidan masih rendah, bahkan ada yang salah dan keliru dalam menerapkan loyalitas hanya ditujukan kepada pimpinannya, tetapi tidak loyal terhadap visi, misi, dan tugas instansinya. Belum optimalnya peran bidan rumah sakit dalam pelayanan KB serta belum maksimalnya sosialisasi dan promosi.

Seiring kemajuan teknologi dan tuntutan masyarakat dalam hal pelayanan, unit penyelenggara pelayanan publik dituntut untuk memenuhi harapan masyarakat dalam melakukan perbaikan pelayanan kesehatan. Persoalan yang kemudian muncul adalah bagaimana menghasilkan karyawan yang memiliki kinerja yang optimal. Kinerja karyawan yang optimal merupakan sasaran organisasi untuk mencapai produktivitas kerja yang tinggi.

RSUD Kota Mataram memerlukan budaya organisasional yang lebih baik lagi, kepuasan kerja dan komitmen organisasional yang tinggi bagi setiap karyawan yang akan mempengaruhi perilaku pelaksanaan tugas maupun hasil yang dicapai. Untuk itu karyawan dalam melaksanakan pekerjaannya dapat menunjukkan suatu sikap yang mencerminkan apa yang dirasakannya, karena sikap pada dasarnya merupakan keteraturan perasaan dan pikiran seseorang dan kecenderungan bertindak terhadap aspek lingkungannya. Pelayanan kesehatan yang dilakukan oleh bidan saat ini belum memenuhi harapan masyarakat. Hal ini dapat diketahui dari berbagai keluhan masyarakat yang disampaikan melalui media masa dan jaringan sosial, sehingga memberikan dampak buruk terhadap pelayanan rumah sakit, yang menimbulkan ketidakpercayaan masyarakat. Sikap atas kepuasan kerja tidak akan tercipta apabila pihak manajemen RSUD Kota Mataram tidak memberikan arahan kepada para bidan, baik bidan dengan status PNS maupun bidan yang berstatus tenaga kontrak. Pembentukan sikap dan perilaku tersebut dapat dilakukan melalui proses pengenalan budaya organisasional kepada para bidan agar mereka dapat bekerja sesuai dengan nilai dan tujuan organisasi. Beberapa bidan juga berpendapat, apabila mereka mendapat pekerjaan pada rumah sakit lain dengan 
penghasilan yang jauh lebih tinggi dibandingkan dengan tempat pekerjaan yang sekarang dan mendapat lingkungan kerja yang nyaman, ini akan menjadi pertimbangan untuk beralih ke tempat pekerjaan tersebut, terutama mereka yang berstatus tenaga kontrak. Hal ini dikarenakan bekerja menjadi karyawan kontrak dirasa sedikit membosankan.

Selain itu para bidan yang berstatus tenaga kontrak merasa bahwa mereka memiliki masa kerja yang tidak pasti dan jenjang karir yang terbatas. Hal ini bisa menjadi pertanda bahwa mereka akan memilih pindah atau meninggalkan organisasinya apabila terdapat pilihan tempat bekerja yang lebih baik. Ini terjadi karena komitmen pada para bidan tergolong rendah. Berbagai hal tersebut menunjukkan rasa kurang pedulinya bidan dengan organisasinya karena komitmen yang rendah. Para bidan melihat bahwa keberadaan mereka dalam organisasi hanya sebatas pelaksana tugas dan mendapatkan imbalan sesuai tugas yang mereka selesaikan.

Berdasarkan fenomena yang terdapat di RSUD Kota Mataram dan adanya research gap yang telah diurakan, maka menjadi menarik untuk melakukan penelitian dan kajian mendalam terkait permasalahan yang terjadi padapara bidan diRSUD Kota Mataram. Dalam penelitian ini difokuskan untuk mengetahui seberapa besar pengaruh budaya organisasional dan kepuasan kerja terhadap komitmen organisasional dan kinerja karyawan.

\section{KAJIAN PUSTAKA}

\subsection{Pengaruh Budaya Organisasional terhadap Kinerja Bidan}

Budaya organisasional adalah sistem nilai-nilai yang diyakini oleh semua anggota organisasi dan yang dipelajari, diterapkan, serta dikembangkan secara berkesinambungan. Budaya organisasional berfungsi sebagai sistem perekat, dan dapat dijadikan acuan berperilaku dalam perusahaan untuk mencapai tujuan perusahaan yang telah ditetapkan.Dengan demikan, secara langsung ataupun tidak langsung budaya organisasional memiliki pengaruh terhadap kinerja organisasi.Penelitian yang dilakukan oleh Khaliq dan Marnis (2015);Nurwati, et.al., (2012); Taurisa dan Ratnawati (2012); berkesimpulan bahwa budaya organisasional berpengaruh positif terhadap kinerja karyawan. Penelitian tersebut juga didukung oleh penelitian Hadian (2015) yang menyimpulkan bahwa budaya organisasional berpengaruh positif dan signifikan terhadap kinerja.

$\mathbf{H}_{1}$ : budaya organisasional mempunyai pengaruh positif dan signifikan terhadap kinerja karyawan.

\subsection{Pengaruh Kepuasan Kerja terhadap Kinerja Bidan}

Kepuasan kerja adalah efek atau respon berupa rasa emosional dari individu terhadap berbagai aspek yang ada di dalam sebuah organisasi. Aspek tersebut dapat berupa rasa senang atau tidak senang, situasi kerja, interaksi dengan orang lain, dan perasaan nyaman akan pekerjaannya itu. Sehingga faktor tersebut memberikan rasa puas kepada individu, dan menjadikan individu itu bekerja lebih keras dan mampu meningkatkan kinerja organisasi. Maesaroh (2016) menyatakan bahwa terdapat pengaruh positif antara kepuasan kerja dengan kinerja karyawan. Penelitian tersebut juga didukung oleh penelitian Chairizal, et.al., (2014); serta Taurisa dan Ratnawati (2012); yang menyimpulkan bahwa kepuasan kerja berpengaruh positif terhadap kinerja karyawan.

$\mathbf{H}_{2}$ : kepuasan kerja mempunyai pengaruh positif dan signifikan terhadap kinerja karyawan. 


\subsection{Pengaruh Budaya Organisasional terhadap Komitmen Organisasional}

Kepatuhan karyawan terhadap peraturan dan norma-norma tersebut menggambarkan usaha para karyawan untuk menjadikan tempat kerjanya nyaman dan menyenangkan, sehingga mereka betah ingin tetap bekerja pada organisasi tersebut. Sebaliknya, apabila karyawan menganggap peraturan dan norma-norma yang ada menjadi beban dan membatasi pilihan mereka, karyawan tersebut akan merasa tidak nyaman berada di organisasi.Hal ini dapat berpotensi melanggar peraturan yang ada, sehingga menimbulkan ketidakteraturan yang menyebabkan karyawan lain terganggu dan pada akhirnya akan melemahkan komitmen karyawan terhadap organisasinya.Budaya organisasional terbukti berpengaruh positif dan signifikan terhadap komitmen organisasional (Yulian, 2015). Hasil penelitian ini mendukung hasil penelitian Taurisa dan Ratnawati (2012).

$\mathrm{H}_{3}$ : terdapat pengaruh positif yang signifikan antara budaya organisasional terhadap komitmen.

\subsection{Pengaruh Kepuasan Kerja terhadap Komitmen Organisasional}

Pekerjaan yang relatif menyenangkan dan rekan kerja yang ramah tentu akan membuat karyawan merasa nyaman dan puas dalam bekerja. Selain itu, gaji yang stabil dan adanya program tunjangan dan pensiun juga memberikan kepuasan bagi para karyawan karena hal ini jarang didapat apabila bekerja ditempat lain. Dengan terpenuhinya kepuasankepuasan tersebut, karyawan tentu akan tetap memilih bekerja di tempat itu dan berusaha sekuat tenaga untuk menjalankan tugas-tugas yang diberikan kepada mereka demi mempertahankan keberadaan mereka di dalam organisasinya. Apabila karyawan keluar dari organisasinya tentu mereka akan merasa rugi karena keuntungan-keuntungan tersebut di atas belum tentu mereka dapat apabila bekerja di tempat lain. Dengan begitu karyawan yang mendapatkan kepuasan kerja selama berada di organisasi itu akan mengalami peningkatan komitmen organisasional mereka.Kepuasan kerja terbukti berpengaruh positif terhadap komitmen organisasional karyawan (Yulian, 2015). Hasil penelitian ini mendukung hasil penelitian Taurisa dan Ratnawati (2012), komitmen organisasional dapat ditingkatkan apabila kepuasan kerja karyawan terpenuhi dengan baik.

$\mathrm{H}_{4}$ : kepuasan kerja berpengaruh positif signifikan terhadap komitmen organisasional.

\subsection{Pengaruh Komitmen Organisasional terhadap Kinerja}

Untuk mencapai efektifitas dalam melaksanakan tugas, karyawan perlu memiliki komitmen yang tinggi terhadap tugas dan organisasi. Komitmen yang tinggi terhadap organisasi akan meningkatkan tanggung jawab dan kesungguhan karyawan dalam melaksanakan tugas. Karyawan yang memiliki komitmen yang tinggi terhadap organisasi akan bekerja sepenuh hati dan akan berjuang demi kemajuan organisasi, karena mereka sadar telah menjadi bagian dari organisasi. Maesaroh (2016) menemukan komitmen organisasional berpengaruh positif signifikan terhadap kinerja. Adanya pengaruh positif berarti semakin meningkatkan komitmen karyawan terhadap organisasi serta meningkatkan kinerja. Temuan dalam penelitian tersebut juga didukung oleh Chairizal, et.al., (2014); serta Taurisa dan Ratnawati (2012).

$\mathrm{H}_{5}$ : komitmen organisasional berpengaruh positif dan signifikan terhadap kinerja. 


\section{METODE PENELITIAN}

Dalam penelitian ini hubungan yang ingin diketehui adalah pengaruh budaya organisasional dan kepuasan kerja terhadap komitmen organisasional dan kinerja BidanRSUD Kota Mataram. Metode pengumpulan data dalam penelitian ini menggunakan sensus/sampel jenuh. Hal ini dikarenakan jumlah populasi dalam penelitian relatif kecil yaitu sebanyak 72 orang. Tingkat pengembalian kuesioner oleh responden daam penelitian ini sangat tinggi $(100 \%)$, hal ini karena peneliti setiap hari datang ke lokasi penelitian selama penyebaran kuesioner. Dari total 72 kuesioner yang diterima, kuesioner yang layak untuk dianalisis sebanyak 72 kuesioner (100\%). Penelitian ini menggunakan analisis model persamaan struktural (analisis SEM) dengan aplikasi Smart PLS.

\section{HASIL DAN PEMBAHASAN}

\subsection{Analisis Data}

Pengujian hipotesis dalam penelitian ini dengan menggunakan analisis Partial Least Square (PLS) dengan program smartPLS 3.0. Model evaluasi PLS berdasarkan pada pengukuran prediksi yang bersifat nonparametik. Pengujian model pengukuran atau outer model digunakan untuk memvalidasi model penelitian yaitu dengan pengujian validitas konstruk (validitas konvergen dan diskriminan), dan pengujian konsistensi internal (reliabilitas konstruk). Sementara, model struktural atau inner model dilakukan dengan memprediksi hubungan kausal antar variabel. Pengujian model struktural dilihat melalui proses bootstrapping,parameter uji T-Statistik. Model struktural (inner model) dievaluasi dengan melihat persentase varians yang dijelaskan oleh nilai $\mathrm{R}^{2}$ untuk konstruk laten dependen dengan menggunakan ukuran Stone-Geisser $Q$ Square Test dan juga dengan melihat koefisien jalur strukturalnya.

Pengujian model pengukuran memberikan gambaran hubungan setiap indikator terhadap variabel latennya, terdapat tiga kriteria untuk menilai suatu model pengukuran yaitu validitas konstruk (validitas konvergen dan diskriminan) dari indikatornya dan composite reliability untuk blok indikator.

Uji validitas konstruk adalah mengukur validitas indikator reflektif sebagai pengukur variabel yang dapat dilihat dari outer loading dari masing-masing indikator variabel. Pada penelitian ini, penelitian mengacu pada nilai skor loading dari Hair, et al (2006). Jadi, jika skor loading< 0,30, indikator ini dapat dihapus dari konstruknya karena indikator ini termuat (load) ke yang mewakilinya. Diketahui bahwa item indikator yang memiliki skor loading < 0,30 akan di-drop atau dihapus. Beberapa item indikator yang di-drop atau dihapus yaitu variabel kepuasan kerja ada 1 (satu) item (X2.01), variabel komitmen organisasional ada 4 (empat) item yaitu Z1.01; Z1.02; Z1.03; dan Z1.08; sementara item pertanyaan yang di-drop dari variabel kinerja bidan yaitu sebanyak 3 (tiga) item yaitu Y1.06; Y1.12; dan Y1.13.

Uji validitas diskriminan bertujuan untuk melihat apakah suatu indikator dari variabel laten tertentu berbeda dari indikator-indikator variabel laten lainnya, sehingga indikator variabel tersebut dapat dianggap layak untuk menjelaskan variabel latennya. Kriteria pertama untuk pengukuran validitas diskriminan indikator reflektif adalah dengan melihat pada cross loading antara indikator dan konstruknya. Kriteria kedua untuk pengukuran validitas diskriminan adalah dengan membandingkan akar dari Average Variance Extracted (Akar AVE) untuk setiap konstruk dengan korelasi antar konstruk dengan korelasi antar konstruk dengan konstruk lainnya dalam model. Model memiliki validitas diskriminan 
yang cukup jika akar AVE untuk setiap konstruk lebih besar daripada korelasi antara konstruk-konstruk lainnya. Diketahui akar AVE dari masing-masing variabel memiliki nilai yang lebih besar dari 0,50. Dengan demikian dapat dinyatakan bahwa keseluruhan variabel dalam model penelitian ini valid.

Uji reliabilitas komposit dapat dilihat dari nilai Cronbach's Alpha dan nilai Composite Reliability. Suatu konstruk dikatakan reliabel, jika memiliki nilai Cronbach's Alpha> 0,60 dan nilai Composite Reliability $>0,70$. Hasil analisis menunjukkan bahwa keseluruhan variabel dalam penelitian ini adalah reliabel. Hal ini ditunjukkan dari nilai Cronbach's Alpha yang > 0,60 dan nilai Composite Reliability pada setiap variabel penelitian yang > 0,70.

Pengujian model struktural dilakukan untuk memprediksi hubungan kausal antar variabel atau pengujian hipotesis, melihat nilai signifikansi, dan $R$-Square model penelitian. Pengujian model struktural bertujuan untuk predictive relevance dan juga melihat besarnya koefisien jalur struktural. Adapun model pengujian struktural dilakukan dalam aplikasi SmartPLS melalui proses bootstrapping.

Nilai $R$-Square digunakan untuk menghitung $Q$-Square test dengan tujuan untuk predictive relevance,yaitu mengukur seberapa baik nilai observasi yang dihasilkan oleh model dan juga estimasi parameternya. Nilai $Q$-Square yang lebih besar dari nol menunjukkan bahwa model memiliki predictive relevance,sedangkan nilai $Q$-Square yang kurang dari nol menunjukkan model yang kurang memiliki predictive relevance.Besaran nilai Q-Square memiliki nilai dengan rentang $0<\mathrm{Q}^{2}<1$, dimana angka $Q$-Square yang semakin mendekati angka 1 maka berarti model semakin baik. Adapun rumus mendapatkan $Q$-Square adalah:

$$
Q^{2}=1-\left(1-R_{1}{ }^{2}\right)\left(1-R_{2}^{2}\right) \ldots . .\left(1-R p^{2}\right)
$$

Tabel 1. Nilai R-Square

\begin{tabular}{cc}
\hline Variabel Dependen & R Square \\
\hline Komitmen Organisasional $(\mathrm{Z})$ & 0,538 \\
Kinerja Bidan $(\mathrm{Y})$ & 0,555 \\
\hline
\end{tabular}

Berdasarkan perhitungan di atas, diperoleh nilai $Q$-Square $=0,508$ atau 50,80 persen. Nilai $Q$-Square ini merupakan nilai untuk budaya organisasional dan kepuasan kerja sebagai variabel independen dalam penelitian ini yang memberikan pengaruh tehadap kinerja bidan melalui komitmen organisasional sebagai variabel intervening dengan nilai sebesar 50,80 persen. Artinya model penelitian ini mempunyai predictive relevance karena memiliki nilai yang lebih besar dari nol, sehingga dapat dinyatakan layak untuk dipergunakan dalam prediksi. Hasil perhitungan ini juga memberikan arti bahwa masih ada 49,20 persen variabel lain yang dapat mempengaruhi kinerja pada bidan di RSUD Kota Mataram.

Selanjutnya pengujian hipotesis penelitian dengan melihat nilai koefisien jalur dan nilai TStatistik. Pengujian koefisien jalur menurut Hartono dalam Jogiyanto (2011), ukuran signifikansi keterdukungan hipotesis dapat digunakan perbandingan nilai T-Tabel dan TStatistik. Jika nilai T-Statistik lebih tinggi dibandingkan nilai T-Tabel, berarti hipotesis terdukung. Untuk tingkat keyakinan 95 persen (alpha 5\%) maka nilai T-Tabel untuk hipotesis dua arah (two-tailed) adalah $\geq 1,64$. Rucker, Preacher, Tomala dan Petty (2011) menjelaskan penggunaan istilah partial mediation dan full mediation dalam membantu menyampaikan ukuran efek atau signifikan praktis dari proses mediasi. Demonstrasi full mediation menyiratkan proses yang mendasari sepenuhnya hubungan variabel inde-penden terhadap variabel dependen, sedangkan demonstrasi partial mediation menyiratkan hubungan secara parsial. 
Tabel 2. Model Struktural (Inner Model)

\begin{tabular}{ccccc}
\hline Hubungan Antar Variabel & Koefisien Jalur & T Statistik & P Values & Keterangan \\
\hline $\mathrm{BO} \rightarrow \mathrm{KB}$ & 0,350 & 2,305 & 0,006 & Signifikan \\
$\mathrm{KK} \rightarrow \mathrm{KB}$ & 0,068 & 0,257 & 0,798 & Tidak Signifikan \\
$\mathrm{BO} \rightarrow \mathrm{KO}$ & 0,565 & 3,385 & 0,000 & Signifikan \\
$\mathrm{KK} \rightarrow \mathrm{KO}$ & 0,682 & 4,479 & 0,000 & Signifikan \\
$\mathrm{KO} \rightarrow \mathrm{KB}$ & 0,510 & 2,600 & 0,010 & Signifikan \\
$\mathrm{BO} \rightarrow \mathrm{KO} \rightarrow \mathrm{KB}$ & 0,288 & 3,563 & 0,000 & Partial Mediation \\
$\mathrm{KK} \rightarrow \mathrm{KO} \rightarrow \mathrm{KB}$ & 0,348 & 2,167 & 0,031 & Full Mediation \\
\hline
\end{tabular}

Hasil pengujian model struktural dapat dilihat pada gambar dibawah ini:

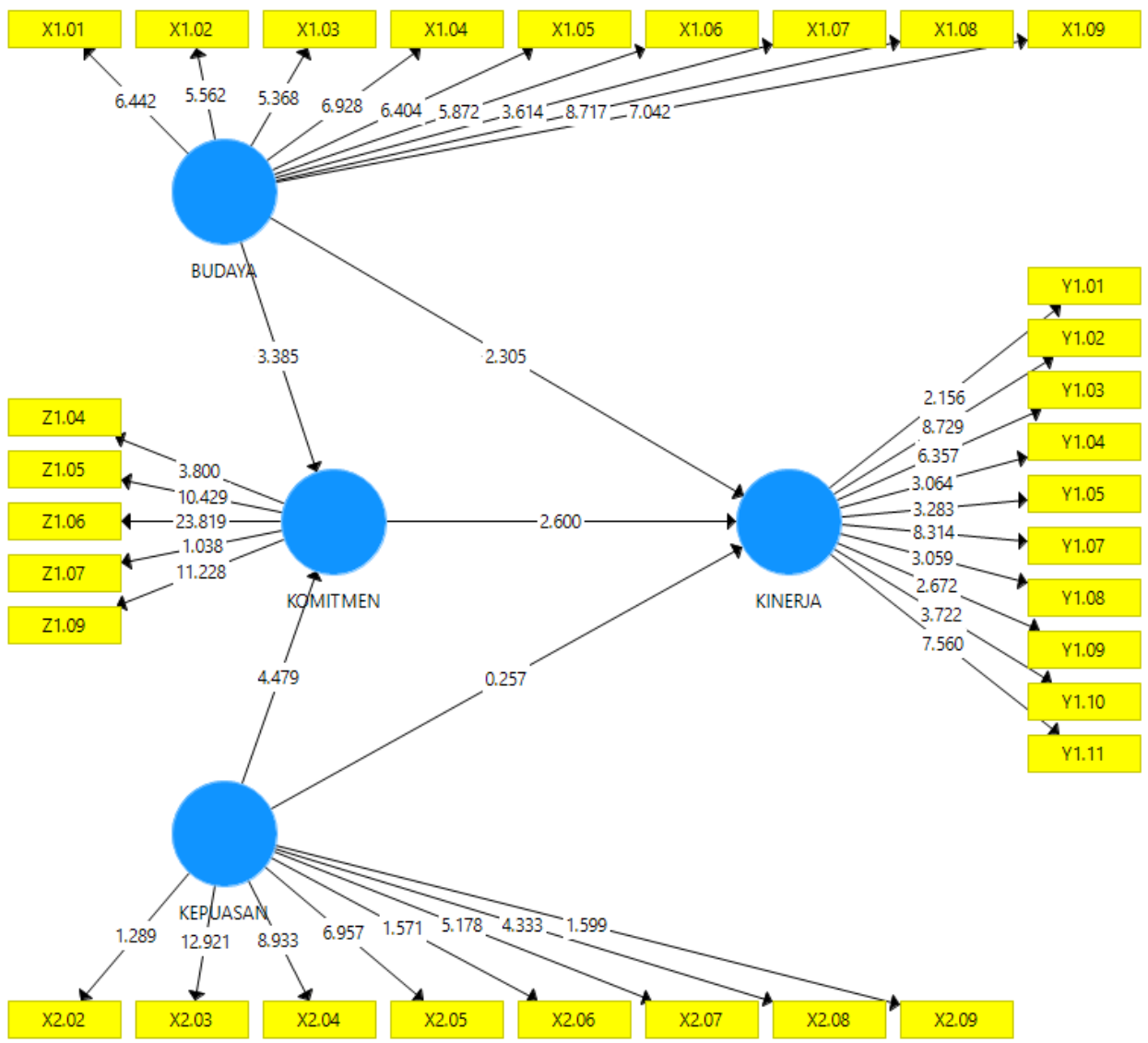

Sumber: Hasil analisis data, 2019

Berdasarkan hasil analisis data menunjukkan bahwa terdapat 6 (enam) hubungan variabel yang memiliki hubungan signifikan, sementara 1 (satu) hubungan variabel lainnya adalah tidak signifikan.

\subsection{Pembahasan}

\subsubsection{Pengaruh Budaya Organisasional Terhadap Kinerja}

Berdasarkan penjelasan dari Gambar dan Tabel nampak koefisien jalur budaya organisasional terhadap kinerja bidan sebesar 0,350 dan p-value sebesar 0,006. Dapat dinyatakan bahwa budaya organisasional berpengaruh positif signifikan terhadap kinerja 
bidan. Artinya jika implementasi budaya organisasional pada RSUD Kota Mataram yang semakin kuat, maka kinerja bidan semakin baik, begitu juga sebaliknya.

Hipotesis pertama menyatakan bahwa budaya organisasional pada bidan di RSUD Kota Mataram berpengaruh positif signifikan terhadap kinerja bidan dimana hipotesis pertama diterima. Hal ini bermakna jika budaya organisasional bidan pada RSUD Kota Mataram tinggi, maka bidan tersebut akan berkinerja baik pada organisasi tempatnya bekerja. Jika dilihat dari data skor rata-rata pendapat responden yang berjumlah 72 orang, maka bidan pada RSUD Kota Mataram memiliki budaya organisasional yang sangat kuat dan tingkat kinerja yang baik. Bersikap ramah dan senyum, sopan santun, serta mutu pelayanan kebidanan terbaik merupakan aspek yang terpenting dalam budaya organisasional yang memiliki pengaruh dominan terhadap kinerja bidan.

Hasil penelitian menemukan budaya organisasional berpengaruh positif signifikan terhadap kinerja bidan di RSUD Kota Mataram. Adanya pengaruh positif berarti semakin baik budaya organisasional di RSUD Kota Mataram maka akan meningkatkan kinerja bidan pada RSUD Kota Mataram. Hasil ini mendukung penelitian sebelumnya yang menyimpulkan bahwa budaya organisasional berpengaruh positif terhadap kinerja. Bidan yang merasa percaya diri terhadap pekerjaannya dan menggangap pekerjaannya sebagai sesuatu yang menyenangkan akan cenderung memiliki kinerja yang baik. Dengan demikian dapatlah disimpulkan bahwa budaya organisasional mempunyai pengaruh positif signifikan terhadap kinerja bidan.

Hasil penelitan ini didukung penelitian sebelumnya yang dilakukan oleh Khaliq dan Marnis (2015); Nurwati, et.al., (2012); Taurisa dan Ratnawati (2012); serta Hadian (2015), menyatakan bahwa variabel budaya organisasional mempengaruhi kinerja. Hal ini menunjukkan bahwa budaya organisasional sangat penting untuk diperhatikan agar meningkatkan kinerja bidan.

\subsubsection{Pengaruh Kepuasan Kerja Terhadap Kinerja Bidan}

Hasil analisis data menunjukkan bahwa kepuasan kerja pada bidan di RSUD Kota Mataram berpengaruh positif tidak signifikan terhadap kinerja bidan. Hipotesis kedua menyatakan bahwa kepuasan kerja berpengaruh positif signifikan, ternyata ditolak. Hal ini dikarenakan seorang bidan yang merasa puas atau tidak puas dengan pekerjaannya tetap mampu berkinerja dengan baik terhadap organisasinya. Berdasarkan data skor rata-rata jawaban responden yang berjumlah 72 orang, menunjukkan bidan di RSUD Kota Mataram dikategorikan kepuasan kerja yang tinggi (puas) dan tingkat kinerja bidan yang baik.

Pengujian hipotesis yang dilakukan membuktikan bahwa terdapat pengaruh yang searah antara kepuasan kerja dan kinerja bidan. Hal ini menunjukkan bahwa semakin tinggi kepuasan kerja yang dirasakan oleh bidan di RSUD Kota Mataram, maka semakin tinggitingkat kinerjanya. Indikator kepuasan kerja yang paling mendominasi adalah kesesuaian pekerjaan dengan bidang keilmuan, di mana hal ini menunjukkan bahwa ketika seorang bidan merasa puas terhadap pekerjaannya, maka ketika itu pula bidan memandang pekerjaannya sebagai sesuatu yang menyenangkan dan cenderung memiliki kinerja yang lebih baik. Hasil penelitian menemukan kepuaan kerja berpengaruh positif tidak signifikan terhadap kinerja bidan di RSUD Kota Mataram. Adanya pengaruh positif berarti semakin meningkat kepuasan kerja bidan maka akan meningkatkan kinerja kerja bidan pada RSUD Kota Mataram.

Dalam rangka memahami kepuasan kerja pegawai, maka seorang pemimpin harus memahami karakteristik masing-masing bawahan. Dengan memahami karakteristik individu maka akan dapat ditentukan pekerjaan yang sesuai karakteristik masing-masing individu. Apabila hal tersebut terwujud maka kepuasan kerja akan dapat tercapai, 
sehingga kinerjanya menjadi lebih baik. Selain itu, kepuasan kerja adalah efek atau respon berupa rasa emosional dari individu terhadap berbagai aspek yang ada di dalam sebuah organisasi. Aspek tersebut dapat berupa rasa senang atau tidak senang, situasi kerja, interaksi dengan orang lain, dan perasaan nyaman akan pekerjaannya itu. Sehingga faktor tersebut memberikan rasa puas kepada individu, dan menjadikan individu itu bekerja lebih keras dan mampu meningkatkan kinerja organisasi.

\subsubsection{Pengaruh Budaya Organisasional Terhadap Komitmen Organisasional}

Hasil analisis data menunjukkan bahwa budaya organisasional pada bidan di RSUD Kota Mataram berpengaruh positif terhadap komitmen organisasional, sehingga hipotesis ketiga yang menyatakan budaya organisasional pada bidan di RSUD Kota Mataram berpengaruh positif signifikan terhadap komitmen organisasional dapat diterima. Artinya jika seorang bidan mengimplementasikan budaya organisasional yang selalu/sering (kuat) dalam pekerjaannya, maka semakin tinggi pula komitmen terhadap pekerjaannya. Implementasi/ penerapan budaya organisasional yang sangat kuat ini dapat meningkatkan komitmen organisasi para bidan.

Pengujian hipotesis yang dilakukan membuktikan bahwa terdapat pengaruh yang searah (positif) antara budaya organisasional dan komitmen organisasional. Hal ini menunjukkan bahwa semakin kuat penerapan budaya organisasional pada RSUD Kota Mataram, maka semakin tinggi komitmen organisasional dalam diri bidan. Dengan demikian, RSUD Kota Mataram perlu menerapkan nilai-nilai serta peraturan-peraturan yang akan mempengaruhi perilaku bidan yang mengarah pada terbentuknya komitmen organisasional. Indikator budaya organisasional yang paling mendominasi adalah sikap sopan santun, di mana hal ini menunjukkan bahwa ketika seorang bidan merasa dihargai dalam sebuah organisasi karena sikap sopan santunnya, maka ketika itu pula tercipta kesepakatan yang tinggi antar bidan mengenai apa yang diyakini organisasi sehingga terbentuk suatu komitmen organisasional dalam diri bidan.

Budaya organisasi adalah sistem makna dan keyakinan bersama yang dianut oleh para anggota organisasi yang menentukan, sebagian besar, bagaimana para karyawan bersikap (Robbins dan Coulter, 2009). Keyakinan yang kuat pada tujuan dan nilai-nilai organisasi oleh para anggotanya sehingga mereka bersedia untuk melakukan usaha-usaha tertentu bagi kepentingan organisasi serta keinginan kuat untuk terus menjadi anggota organisasi yang merupakan bentuk dari sebuah komitmen organisasi (Steer dan Porter, 1991). Artinya semakin baik budaya yang ada pada sebuah organisasi maka para anggota akan yakin dan menjadikan budaya organisasinya sebagai pedoman dalam menjalankan tugas, sehingga hal itu memperkuat komitmen mereka terhadap organisasinya.

Budaya organisasi terbukti berpengaruh positif terhadap komitmenorganisasional bidan. Hasil penelitian ini mendukung hasil penelitian Yulian (2015) yang menunjukkan bahwa terdapat pengaruh yang searah antara budaya organisasional terhadap komitmen pegawai.Hasil penelitian menemukan budaya organisasional berpengaruh positif signifikan terhadap komitmen bidan di RSUD Kota Mataram. Adanya pengaruh positif berarti,jika semakin kuat budaya organisasional di RSUD Kota Mataram maka akan meningkatkan komitmen bidan terhadap organisasi. Hasil penelitian ini mendukung penelitian sebelumnya seperti Taurisa dan Ratnawati (2012) yang menyimpulkan bahwa budaya organisasional mempunyai pengaruh yang positif terhadap komitmen organisasional.

\subsubsection{Pengaruh Kepuasan Kerja Terhadap Komitmen Organisasional}

Hasil analisis data menunjukkan bahwa terdapat pengaruh yang positif signifikan dari kepuasan kerja para bidan pada RSUD Kota Mataram terhadap komitmen organisasional. 
Hipotesis keempat dalam penelitian mengatakan bahwa kepuasan kerja berpengaruh positif signifikan terhadap komitmen organisasional, dapat diterima.Hasil penelitian yang dilakukan Yulian (2015) meneliti kepuasan kerja terhadap komitmen organisasional, mengungkapkan bahwa tenaga pekerja garis depan yang mengalami kepuasan kerja akan merasakan komitmen organisasional dan dapat menujukkan kinerja yang diharapkan.

Hasil penelitian menunjukkan bahwa kepuasan kerja berpengaruh positif signifikan terhadap komitmen organisasional. Hal ini dibuktikan dengan hasil perhitungan statistik inferensial. Kontribusi pengaruh kepuasan kerja terhadap komitmen organisasional cukup besar, maka dapat disimpulkan bahwa hipotesis keempat dalam penelitian ini dapat diterima. Wexley dan Yukl dalam Suwatno dan Donni (2011) menjelaskan bahwa kepuasan kerja adalah perasaan seseorang terhadap pekerjaannya. Kepuasan kerja secara umum merupakan sikap terhadap pekerjaan yang didasarkan pada evaluasi terhadap aspek-aspek yang berbeda dari pekerjaan. Sikap seseorang terhadap pekerjaannya itu menggambarkan pengalaman-pengalaman menyenangkan atau tidak menyenangkan dalam pekerjaan dan harapan-harapannya mengenai pengalaman mendatang.

Hasil penelitian menemukan kepuasan kerja berpengaruh positif signifikan terhadap komitmen bidanpada organisasi RSUD Kota Mataram. Adanya pengaruh positif berarti semakin meningkat kepuasan kerja bidan di RSUD Kota Mataram maka akan meningkatkan komitmen bidanterhadap organisasi RSUD Kota Mataram. Hasil ini mendukung penelitian sebelumnya diantaranya adalah penelitian Taurisa dan Ratnawati (2012) serta Yulian (2015), menunjukkan hasil bahwa adanya pengaruh positif dan signifikan kepuasan kerja terhadap komitmen organisasional yang artinya semakin tinggi kepuasan kerja semakin tinggi komitmen organisasional. Dengan kepuasan kerja yang tinggi pada setiap diri bidan akan mendorong para bidan untuk memberikan komitmen mereka pada organisasi, dengan komitmen yang ada secara tidak langsung akan memberikan dorongan pada kinerja.

Modway et al., dalam Fajariyanti (2003) menyatakan bahwa komitmen organisasional merupakan itikad yang kuat seseorang untuk terlibat dalam suatu organisasi. Kepuasan kerja menyangkut sikap pegawai yang menunjukkan perasaan senang atau tidak senang terhadap organisasinya. Norris dan Niebuhr (1993) menyatakan semakin banyak aspekaspek nilaidalam perusahaan yang sesuai dengan dirinya maka semakin tinggi tingkat kepuasan yang dirasakan.

\subsubsection{Pengaruh Komitmen Organisasional Terhadap Kinerja}

Hasil analisis data menunjukkan bahwa terdapat pengaruh yang positif signifikan dari komitmen organisasional bidan di RSUD Kota Mataram terhadap kinerja bidan. Hipotesis yang menyatakan bahwa komitmen organisasional berpengaruh positif signifikan terhadap kinerja bidan terbukti dan dapat diterima. Hal ini berarti bahwa jika para bidan memiliki komitmen semakin tinggi dengan pekerjaannya membuat bidan menunjukkan kinerja semakin baik terhadap organisasinya. Sebaliknya jika semakin rendah komitmen organisasional bidan, maka semakin rendah (kurang baik) pula kinerja bidan di RSUD Kota Mataram.

Pengujian hipotesis yang dilakukan membuktikan bahwa terdapat pengaruh yang searah antara komitmen organisasional dan kinerja bidan. Hal ini menunjukkan bahwa semakin tinggi komitmen organisasional dalam diri bidan di RSUD Kota Mataram, maka semakin tinggi tingkat kinerja bidannya. Indikator komitmen organisasional yang paling mendominasi adalah perasaan menjadi bagian dari organisasi, di mana hal ini menunjukkan bahwa ketika seorang bidan merasa menjadi bagian dari sebuah organisasi 
tempat mereka bekerja, maka ketika itu pula mereka dapat memberikan kontribusi dan berperan dalam mencapai tujuan organisasi yang akan mempengaruhi kinerjanya.

Hasil penelitian menemukan komitmen organisasi berpengaruh positif signifikan terhadap kinerja bidan di RSUD Kota Mataram. Adanya pengaruh positif berarti semakin meningkatkan kepuasan kerja bidan di RSUD Kota Mataram dan akan meningkatkan komitmen bidan terhadap organisasi serta meningkatkan kinerja bidan di RSUD Kota Mataram. Untuk mencapai efektifitas dalam melaksanakan tugas, bidan perlu memiliki komitmen yang tinggi terhadap tugas dan organisasi. Komitmen yang tinggi terhadap organisasi akan meningkatkan tanggung jawab dan kesungguhan bidan dalam melaksanakan tugas. Bidan yang memiliki komitmen yang tinggi terhadap organisasi akan bekerja sepenuh hati dan akan berjuang demi kemajuan organisasi, karena mereka sadar telah menjadi bagian dari organisasi.

\section{KESIMPULAN}

Berdasarkan hasil analisis statistik inferensial dapat disimpulkan budaya organisasional berpengaruh positif dan signifikan terhadap kinerja. Kepuasan kerja berpengaruh positif, tidak signifikan terhadap kinerja. Budaya organisasional berpengaruh positif dan signifikan terhadap komitmen organisasional. Kepuasan kerja berpengaruh positif signifikan terhadap komitmen organisasional. Komitmen organisasional berpengaruh positif signifikan terhadap kinerja bidan. Kinerja bidan dipengaruhi oleh budaya organisasional dan komitmen organisasional berfungsi sebagai variabel perantara (partial mediation) antara budaya organisasional terhadap kinerja bidan. Kinerja bidan dipengaruhi oleh kepuasan kerja melalui komitmen organisasional sebagai variabel intervening pada bidan di RSUD Kota Mataram.

\section{DAFTAR PUSTAKA}

Chairizal, T.N., Ningsih, D.S., dan Nuryanti, 2014, Pengaruh Stres dan Kepuasan Kerja terhadap Kinerja Perawat Rumah Sakit Ibu dan Anak Eria Bunda Pekanbaru, JOM FEKON, 1 (2): 1-17.

Ghozali, I., dan Latan, H., 2012, Partial Least Square Konsep, Teknik dan Aplikasi SmartPLS, Semarang: BP Universitas Diponegoro.

Gibson, Ivancevich dan Donnelly, 1997, A Diagnostic to Organizational Behavior, Boston : Allyn and Bacon.

Hadian, D., 2015, Pengaruh Kepemimpinan, Struktur Organisasi dan Budaya Organisasi terhadap Kinerja Dinas serta Implikasinya pada Pelayanan Publik, Jurnal Kontigensi, 3 (1): 26-43.

Hasibuan, M.S.P., 2009, Manajemen Sumber Daya Manusia, Jakarta: Bumi Aksara.

Hidayah, T., dan Tobing, D.S.K., 2018, The Influence Of Job Satisfaction, Motivation, and Organizational Commitment To Employee Performance, International Journal of Scientific \& Technology Research, 7 (7): 122-127.

Jex, S.M., 2002, Organizational Psychology: A Scientist-Practitioner Approach, United States of America: John Wiley \& Sons, Inc.

Kast, F.E., dan Rosenzweig, J.E., 2002, Organisasi dan Manajemen, Jilid I, Edisi Keempat, Jakarta: Bumi Aksara. 
Khaliq, I., dan Marnis, 2015, Pengaruh Budaya Organisasi, Disiplin Kerja Dan Kepemimpinan Terhadap Kinerja Pegawai Pada Sekretariat Daerah Kabupaten Indragiri Hulu, Jurnal Tepak Manajemen Bisnis, 7 (1).

Kotler, J.P., dan Heskett, J.L., 1997, Corporate Culture and Performance, New York: The Free Press.

Kreitner, R., dan Kinicki, A.J., 2005, Perilaku Organisasi Buku 1, Jakarta: Salemba Empat.

Luthans, F,. 2006, Performance and Motivation, New York: Prentice Hall.

Maesaroh, S., 2016, Analisis Mengenai Pengaruh Budaya Organisasi dan Kepuasan Kerja terhadap Komitmen Organisasi dalam Meningkatkan Kinerja Karyawan (Studi pada PT. Sampharindo Perdana), Jurnal Manajemen Dian Nuswantoro (UDINUS).

Mangkunegara, A.A., 2011, Manajemen Sumber Daya Manusia Cetakan Ketujuh, Bandung: Remaja Rosdkarya.

Martoyo, S., 2000, Manajemen Sumber Daya Manusia, Edisi Keempat, Yogyakarta: BPFE.

Maurice, 1999, Pengukuran Kinerja Sektor Publik, Yogyakarta: BPFE.

Minner, J.B., 1992, Industrial Organization Psychology: International Edition Psychology Series, New York: McGraw-Hill.

Mowday, R., Steers, R., dan Porter, L., 1979, The Measurement of Organizational Commitment, Journal of Vocational Behavior, 14 (1): 224-247.

Muthuveloo, R., dan Rose, R.C., 2005, Typology of Organizational Commitment, American Journal of Applied Science, 2 (6): 1078-1081.

Nurwati, Nimran, U., Setiawan, M., dan Surachman, 2012, Pengaruh Kepemimpinan terhadap Budaya Organisasi, Komitmen Kerja, Perilaku Kerja dan Kinerja Pegawai (Studi pada Satuan Kerja Perangkat Daerah Propinsi Sulawesi Tenggara), Jurnal Aplikasi Manajemen, 10 (1): 1-11.

Prawirosentono, S., 1999, Kebijakan Kinerja Karyawan, Yogyakarta: BPFE.

Riduwan, dan Kuncoro, E.A., 2012, Cara Menggunakan Path Analysis (Analisis Jalur), Bandung: Alfabeta.

Rivai, V., dan Sagala, E.J., 2013, Manajemen Sumber Daya Manusia Untuk Perusahaan, Dari Teori ke Praktik, Edisi Kedua, Jakarta: Rajawali Pers.

Robbins, S.P., 2006, Perilaku Organisasi Edisi ke-10, Jakarta: Indeks.

Robbins, S.P., dan Judge, T.A., 2008, Perilaku Organisasi,Jakarta: Selemba Empat.

Sekaran, U., 2006, Research Methods For Business, Terjemahan, Buku 2, Edisi 4, Jakarta: Salemba Empat.

Setiawan, R., dan Lestari, E.P., 2016, Pengaruh Budaya Organisasi, Komunikasi, Lingkungan Kerja Dan Motivasi Terhadap Komitmen Organisasi Dalam Meningkatkan Kinerja Pegawai, Jurnal Organisasi dan Manajemen, 12 (2): 169-184.

Silalahi, U., 2010, Metode Penelitian Sosial, Bandung: Refika Aditama.

Simamora, H., 2004, Manajemen Sumber Daya Manusia, Yogyakarta: STIE.

Simanjuntak, P.J., 2005, Manajemen dan Evaluasi Kinerja, Jakarta: LPFE UI.

Siregar, S., 2013, Metode Penelitian Kuantitatif, Jakarta: Kencana.

Siswanto, S., 2005, Manajemen Tenaga Kerja Indonesia Edisi Kedua, Jakarta: Bumi Askara.

Sopiah, 2008, Perilaku Organisasi, Yogyakarta: Andi Offset.

Srimulyani, V.A., 2009, Tipologi dan Anteseden Komitmen Organisasional, Jurnal Ilmiah Widya Warta, 33 (1): 41-52.

Sudjana, 2000, Metoda Statistik, Bandung: Tarsito.

Sugiyono, 2016, Metode Penelitian (Pendekatan Kuantitatif, Kualitatif, dan R\&D), Bandung: Alfabeta. 
Supangat, 2008, Analisis Kinerja Perawat dan Kepuasan Pasien di Rumah Sakit Dr. H. Ibnu Sutowo dan Puskesmas Rawat Inap di Baituraa Kabupaten Oku, Tesis tidak dipublikasikan, Yogyakarta: Universitas Gadjah Mada.

Suprihantono, J., 2001, Penilaian Pelaksanaan Pekerjaan dan Pengembangan Karyawan, Yogyakarta: BPFE.

Suwatno, dan Donni, J.P., 2011, Manajemen SDM dalam Organisasi Publik dan Bisnis, Bandung: Alfabeta.

Taurisa, C.M., dan Ratnawati, I., 2012, Analisis Pengaruh Budaya Organisasi dan Kepuasan Kerja Terhadap Komitmen Organisasi Dalam Meningkatkan Kinerja Karyawan (Studi pada PT. Sido Muncul Kaligawe Semarang), Jurnal Bisnis dan Ekonomi (JBE), 19 (2): 170-187.

Yulian, F., 2015, Pengaruh Budaya Organisasi dan Kepuasan Kerja Terhadap Komitmen Organisasi Untuk Meningkatkan Kinerja Pegawai, Jurnal Kinerja, 12 (1): 44-59.

Yulianti, P., 2015, Komitmen Organisasi Perspektif: Konsep dan Empiris, Jurnal Studi Manajemen dan Bisnis, 2 (1): 52-62.

Yuwono, S., Purwanto, Y., dan Kurniawan, A., 2006, Hubungan Antara Persepsi Manajemen Lini Terhadap Turnover di Manajemen Puncak Dengan Komitmen Organisasi, Jurnal Siasat Bisnis (JSB), 11 (2): 181-188. 